\title{
CHARACTER VALUES IN TEACHING NARRATIVE TEXT AT STATE SENIOR HIGH SCHOOL OF PAMEKASAN
}

\author{
Jamaludin \\ SMA Wachid Hasyim Pamekasan \\ (willnway@yahoo.com) \\ Ahmad Munir \\ Fakultas Bahasa dan Seni, Unesa \\ (munstkip@yahoo.com)
}

\begin{abstract}
Abstrak
Artikel ini mencoba untuk menjawab pertanyaan tentang apa karakter nilai-nilai yang terintegrasi dan bagaimana guru bahasa Inggris mengintegrasikan nilai-nilai karakter dalam proses belajar mengajar teks narasi di SMA Negeri Pamekasan. Penelitian deskriptif kualitatif digunakan dalam penelitian ini. Teknik pengumpulan data yang digunakan adalah wawancara dan observasi. Peserta penelitian ini adalah semua siswa XI-F SMAN 1 Pamekasan. Temuan penelitian ini, ada enam nilai-nilai karakter yang guru bahasa Inggris terintegrasi melalui dua teks naratif berjudul "Raja Arthur dan Donkey, Tabel, dan Stick" yaitu menjadi gemar membaca, mandiri, komunikatif, ingin tahu, pekerja keras, dan disiplin . Secara umum ada dua langkah yang guru dilaksanakan untuk terintegrasi nilai-nilai karakter. Yang pertama adalah memilih nilai-nilai karakter tertentu berdasarkan kata kerja yang digunakan dalam indikator pembelajaran. Yang kedua adalah mengintegrasikan nilai karakter yang dipilih dalam proses belajar mengajar teks narasi bahasa Inggris.
\end{abstract}

Kata kunci: Pendidikan karakter, nilai-nila karakter, teks naratif

\section{A. INTRODUCTION}

Nowadays, Indonesia has many kinds of problems such as corruption, violence, sex crimes, vandalism, etc. which the actors are often found from educated people such as the members of parliament, leader of region, government's officers and also students. It needs to solve the problem soon to create a good atmosphere wherever somebody lives.

Education is considered as an alternative institution to prevent the problem because education can build a new better generation (Mendiknas, 2010). The way to prevent is by integrating character values in teaching and learning process. The integration of character values is a national movement creating schools that foster ethical, responsible, and caring young people by 
modeling and teaching good character through emphasis on universal values that teachers share (Lickona, Schaps, \& Lewis, 2007).

Character refers to those aspects of personality that are shaped through experience, training, or socialization process (Miller, Kraus, \& Veltkamp, 2005). Character developed in schools based on virtues of individual character. Because humans live in social and in particular culture, the development of individual character can only be done in a social and cultural environment. That is, the development of character can only be done in an educational process which does not release students from the social, cultural, and national culture.

To be effective, the integration of character values must include the entire school community and must permeate the entire school curriculum and culture (Partnership, 2008). The character is woven into policies of the schools, programs, practices, and interactions between teachers with learners, teachers with schools staff, learners with other learners etc. so the students can remember and practice the character wherever and whenever they act in their school.

The integration of character values is relevant with the law of education about national education system in Indonesia. Section 3 explains that:

"Pendidikan nasional berfungsi mengembangkan dan membentuk watak serta peradaban bangsa yang bermartabat dalam rangka mencerdaskan kehidupan bangsa, bertujuan untuk berkembangnya potensi peserta didik agar menjadi manusia yang beriman dan bertakwa kepada Tuhan Yang Maha Esa, berakhlak mulia, sehat, berilmu, cakap, kreatif, mandiri, dan menjadi warga negara yang demokratis serta bertanggung jawab” (Indonesian Goverment, 2003).

It means that the function of national education is to develop and shape the good character in the context of the intellectual life of the nation, aimed at developing students' potentials to be faithful to God, healthy, knowledgeable, skilled, creative, independent, and democratic and accountable citizen. 
In general, there are eighteen characters which must be integrated into Indonesian education curriculum (Mendiknas, 2010). Those include being religious, honest, tolerant, discipline, hardworking, creative, independent, democratic, inquisitive, nation enthusiasm, loyal, respectful, communicative, joyful, fond of reading, caring, sensitive, and responsible. The values of those characters can be integrated in every subjects existing in senior high school include in English lesson.

English becomes an important lesson to integrate character values because the primary purpose of teaching English is developing pupils' intellectual abilities and cultivation of character, moral, cultural and aesthetic values (Poulson, 1998). Teachers are expected to integrate the appropriate character values in every English skills while they teach English at classroom.

Specifically, Mendiknas (2010) states that there are eight character values which English teachers should integrate in the process of teaching and learning English. They involve being discipline, hardworking, independent, democratic, inquisitive, communicative, fond of reading and caring.

Primarily, the values of the eight characters are applicable for all English skills; listening, speaking, reading, and writing. Meanwhile, the writer focuses the character integration on teaching English narrative for three reason; narrative texts have a certain moral values, narrative texts are widely read by adolescents and narrative are a staple of secondary English curricula (Bohlin, 2005).

The integration of character values in Indonesian school is particularly important in today's society for some reasons. The first Indonesian youth face many opportunities and dangers unknown to earlier generations. They are bombarded with many more negative influences through the media and other external sources prevalent in today's culture. The second the integration of character values can create safe school. It means, it can help students feel safe because they are in an atmosphere that respect, responsibility etc are implemented. The third character integration can help students not only smart 
but also good. So the students are able to do something useful for their own life, family, and society.

In fact, the attitude of senior high school students is not as good as educationalists hope although the issues of integration of character values has been discussed since 2010. Juvenile delinquency is usually found. The actors of the delinquency are often students of junior or senior high school. In relation with this event, King (2008) states in his dissertation that the disruptive behavior was high and increased as the students moved to a higher grade level. In addition to King's (2008) statement, Ishii (2010) in his dissertation states that teachers are not role model of good character practice. He found that teachers were only being role in limited time. Salahuddin (2011) also states in his dissertation that the school delivers its character education curriculum primarily through the Islamic studies division. It is very possible that the above findings are the reasons why the actors of juvenile delinquency are senior high school students although the integration of character values has already implemented.

The findings of the three previous studies show that none of them explored the integration of character values in English language teaching specially in teaching narrative. Therefore, a study on how character values are integrated in senior high school with high incidence of disruptive behavior is needed. This study will fill in this gap. In other words, this study will explore how an English teacher integrated character values in teaching teaching narrative texts in a senior high school in Pamekasan.

This study explored the integration of character values in teaching narrative. Qualitative research is considered appropriate strategy because of its ability to provide complex descriptions of how people experience a given research issue. It provides information about the "human" side of an issue-that is, the often contradictory behaviors, beliefs, opinions, and relationships of individuals (Mack, woodsong, Macqueen, Guest, \& Namey, 2005). Strauss and Corbin (in Hatch, 2002) states that qualitative research is any kind of research 
that produces findings that are not arrived at by means of statistical procedures or other means of quantification.

Further Hatch (2002) states that there are some kinds of qualitative research. One of them is qualitative case study research used in this study to investigate a contextualized phenomenon within specified boundaries-that is the integration of character values through teaching English narrative.

Cohen, Manion, and Morrison (2007) state that case study strives to portray particular situation, to catch the close up reality and 'thick description 'of participants' lived experiences of, thoughts about and feelings for a situation. In this study, the writer will try to portray the integration of character values in the process of teaching and learning narrative, and the kind of characters integrated in the process of teaching and learning English narrative. This case study could contribute to enhance and deepen writer's understanding of the core essence of the integration of character values, which might be epitomized in SMAN 1 Pamekasan.

The participants in this research are students and English teacher of SMAN 1 Pamekasan. The writer focused this study on the F eleventh grade students (XI F) in the second semester of 2012/2013. The class consists of thirty two (32) students. Nine of them are male students and twenty three students are female.

The English teacher of the class is Heny Sari Rosa. She has already taught English since 2001. She has already joined some training. One of the training that she followed is training of trainer (TOT) for character education that teacher should integrate in teaching and learning process include in English language teaching.

The class is selected because the English teacher of the class is one of member in training of trainer (TOT) of character education. The teacher has more capability to integrate character values through teaching English than the other ones who never join with TOT program. The fact leads the writer to investigate his way to integrate the values of eight characters in teaching narrative. 
The data collected in this research is teacher's action and teacher's statements in relation with the integration of character values in teaching and learning narrative process. There are two procedures to collect data in this research.

The first technique to collect data is interview. Bogdan and Biklen (1992) explained, interview is a purposeful conversation, usually between two people that is directed by one in order to get information. Somebody was interviewed in this study is the English teacher of the eleventh grade (XIF) in SMAN 1 Pamekasan. The researcher used unstructured interview because the researcher needed to find data about the integration of character values in teaching narrative as much as possible and wanted to keep the natural conversation with the English teacher.

Data collected through interview is English teacher's statement in relation with the integration of character values in teaching narrative. In conducting the interview with the English teacher, researcher recorded the teacher's statements so the interview ran well like natural conversation. The result of the interview was transcribed whether those statements are relevant with the integration of character values or not. The result of this interview used to answer the first research question.

The second technique used collect data is observation. Hatch (2002) states that observation is an effort to see something through eyes of thing that researcher is studying. In this case, the writer observed teaching and learning English narrative in relation with the integration of character values. The observation conducted in the F elevent grade (XIF) of SMAN 1 Pamekasan. The observation conducted for the second semester of 2012/2013. Participant observation used in this study because the writer wanted to discern ongoing behavior as it occurs and make appropriate note about salient feature.

Data collected through observation is teacher activity in the process of teaching narrative to integrate character values in English classroom. There are two narrative texts that teacher discussed as long as researcher observing the class. The first narrative entitled "King Arthur." It was discussed for two days 
on $23^{\text {rd }}-24^{\text {th }}$ April 2013. The second discussion was held on $28^{\text {th }}-29^{\text {th }}$ May 2013. The story discussed entitled "the Donkey, the Table, and the Stick."

In the observation that researcher held for the two topics of narrative, researcher took note of the English teacher's action in number form. It was held to classify the teacher's activity used to integrate character values or no. Researcher used observation sheet to note teacher's and students' action as long as the discussion of the two story was being held in the classroom. The result of the observation used to answer the first research question proposed in this study.

Analysis and review of the interviews notes or transcripts, as well as field notes of observations was conducted for long time and continued immediately after the fieldwork phase. The continual analysis in qualitative research where data is reviewed again and again is essential. I narrowed topics down to what was relevant to the research questions, which were evident from participants' comments or from my field notes. An equal emphasis on participants' observation and unstructured interview was made because written materials leave out large amount of vital information even in the most meticulous transcripts.

\section{B. FINDINGS AND DISCUSSION}

In general, there are two techniques that teacher implemented to integrate character values in teaching English specifically in the process of teaching narrative of the two stories entitle King Arthur and the Donkey, the Table, and the Stick,"

The first technique that the English teacher did was analyzing the learning indicators of the stories taught. The indicators are analyzed because they are as tools meant to describe the quality, the effectiveness, the equity or the trends of a particular aspect of the education system. The teacher matched the verb of the indicators with the list of the eight character values that he integrated in teaching English include in teaching narrative text. 
The character values that teacher selected in this narrative text involve being fond of reading, communicative, independent, and inquisitive. The character values are selected based on the verb used in each learning indicators of "King Arthur" story.

In general, the verb used in learning indicators of King Arthur story could be classified into four parts. First is " read and re-read". The two previous verbs led the English teacher of the F eleventh grade in SMAN 1 Pamekasan to select "fond of reading" values. The second is "correcting the mistake pronunciation orally, discussing the meaning of difficult words, answering some other students questions, and sharing students' understanding to the other students. The second classification of the verb led the English teacher to integrate "communicative" values in discussing "King Arthur" story. the third is " finding out the word meaning using dictionary and identifying difficult words, language features, generic structures, and adverb clause used in the story". The third classification led the teacher to integrate "independent" value in discussing "King Arthur" story. The fourth is "analyzing the content of the story, and asking complex question". The fourth classification led the teacher to integrate "inquisitive" value.

The second technique that teacher implemented to integrate character values was designing teaching and learning process aimed at internalizing the character values in students' daily practice. The character values that teacher integrated in teaching narrative of the two stories encompass being fond of reading, independent, communicative, inquisitive, hardworking, and discipline. Those all are some of the eight characters that teacher should integrate. However, two character values are not integrated in the process of teaching the two stories. They are democratic and caring. They were not selected because there are not any indicators of the two stories aimed at develop the two values.

In general, the verb used in learning indicators of King Arthur story could be classified into four parts. First is " read and re-read". The two previous verbs led the English teacher of the F eleventh grade in SMAN 1 Pamekasan to select "fond of reading" values. The second is "correcting the 
mistake pronunciation orally, discussing the meaning of difficult words, answering some other students questions, and sharing students' understanding to the other students. The second classification of the verb led the English teacher to integrate "communicative" values in discussing "King Arthur" story. the third is " finding out the word meaning using dictionary and identifying difficult words, language features, generic structures, and adverb clause used in the story". The third classification led the teacher to integrate "independent" value in discussing "King Arthur" story. The fourth is "analyzing the content of the story, and asking complex question”. The fourth classification led the teacher to integrate "inquisitive" value.

Teaching and learning activity shows that the activities that teacher did are her ways to integrate the appropriate character values in the process of teaching the two stories: King Arthur, and The Donkey, the Table, and the Stick. those activities are selected to keep the process of teaching and learning English run naturally and to help students practice the values especially in the English language learning without learning the values like learning the English its self.

The first value that teacher integrated was fond of reading. It was selected because the indicator of the story discussed led the teacher to do it. The first indicator is "students read the story based on the generic structure of the two stories" The teacher reasoned that the verb "read" of the learning indicator is the clue for the English teacher to select the value. The selection of "fond of reading" value based on the verb "read" in the learning indicator is relevant with the consideration for eight character values that teacher should integrate in the process of teaching English include in teaching narrative text. The considerations of selecting this value are "students read more references than teachers recommend, and Students like to read general books such newspaper, magazine etc."

The two considerations above are the guidance for an English teacher to integrate "fond of reading" value in the process of teaching English especially 
in teaching narrative text. The techniques to integrate the value that teacher implemented is adjusted with the topic that teacher discussed.

The English teacher's effort to help students being "fond of reading" is asking five students read the story entitled "King Arthur" and three students to read the story entitled "The Donkey, The Table, and The Stick".. Getting students to read the two stories is the teacher effort to internalize the "fond of reading" value in or out of school. By being fond of reading, students can read more references than teachers recommended and students like to read general books such newspaper, magazine etc. which can help them to enrich their knowledge in the lesson that they learn and other knowledge needed to help them easy to communicate with others outside school.

Some other techniques that the English teacher implemented to internalize "fond of reading," especially in teaching "King Arthur" story namely instructing students to re-read the story to answer some questions correctly to students' questions and to conclude the content of the story.

In relation to "fond of reading" integration, students was only doing what their teacher said. Students seemingly obeyed to every commands of their teacher statements. The students' activity was reading, re-reading to check some other students' answer and reading again to conclude the story. although the students' action are same but the result of their conclusion is automatically the same. Because teacher basically provided a chance for the students to increase their knowledge through the "King Arthur" discussion.

The second character value that teacher integrated in teaching narrative is being independent. The value is selected in teaching English especially in discussing "King Arthur, and The Donkey, The Table, and The Stick" because the learning indicators of the two stories refer to the "independent" value. There are two considerations that teacher may use as proposition to integrate the value. The two considerations are "Students find an extra English sources in library to finish their task without librarian help, and Students themselves translate English text to Indonesia and from Indonesia to English." The two indicators of character integration led the English teacher to select 
"independent" value in process of teaching the two stories; King Arthur and The Donkey, The Table, and The Stick.

There are five learning indicators that teacher used as proposition to insert the character value in both stories three of the five indicators are "King Arthur" learning indicators namely students identify the meaning of story, students decide the main idea of each paragraph in the story, and students identify language features of the "King Arthur" story. While the two of the five indicators are "the Table, the Donkey, and the Stick" learning indicators namely students arrange paragraph to be a complete narrative text, and students can write a narrative text individually.

As the learning indicators of the two stories are different, the techniques that teacher implemented to integrate the "independent" value are also different. In general there are three techniques that teacher implemented in "King Arthur" discussion. For the first day of the discussion, teacher instructed students to identify the difficult word they found in the story, teacher instructed students to find out the words meaning identified by themselves by guessing or finding it in dictionary, and teacher instructed students identify the language features of "King Arthur" story.

Students' responds to the instructions encompassed selecting some difficult words of the "King Arthur" story and writing the words on the white board. The words written involve: stepped (pr.3), knelt (pr.3), stamped (pr.4), shield (pr.5), mounted (pr.7), cheered (pr. 8), armor (pr.11), horn (pr.14), charged (pr.15), grabbed (pr.16).

On the following day of "King Arthur" discussion, teacher also implemented three techniques to integrate the "independent" value namely instructing students to identify the generic structure of the story and explain the general content of each structure, instructing students to identify the language features of the story and explain the reason of the usage, and instructing students to identify the adverb clause used in the story.

The students' activities in the classroom were mentioning the generic structure of the story and explained the content of the narrative structure. They 
also the language features. They said that almost sentence of the story are using simple past. The last activity for "independent" value, students tried to find out the explicit adverb clause of the story but they didn't get it. They explain to their teacher that there are no any adverb clause used in "king Arthur" Story.

While the learning indicators of "the Donkey, the Table, and the Stick story to integrate the "Independent" value are students arrange paragraph to be complete narrative text, and students can create narrative text individually. Based on the two indicators the techniques that teacher implemented involve instructing students to identify the language features of the story, instructing students to correct other students' mistake in answering a question, and correcting the mistake of the English punctuation usage and instructing students to make narrative y their own.

Based on the teacher's instruction, students identify the features of "the Donkey, the Table, and the Stick" story. As soon as they finished it, they wrote narrative text which the topic is based on their interest. Fifteen minutes later, some students consulted their work to the teacher.

Those techniques were basically implemented to help students to be independent especially to find an extra English sources in library to finish their task without librarian help and students themselves translate English text to Indonesia and from Indonesia to English. The integration of this value can also help students to solve their problem especially in English lesson in or out of school.

The third character integrated in teaching narrative is "communicative" value. It was selected in teaching narrative text entitled King Arthur, and The Donkey, The Table, and The Stick because the learning indicators of the stories refer to the considerations of the value. There are three considerations that teacher may use as guidance to integrate communicative value. Those are students ask or give an opinion while discussion is held, students listen to teachers or other students' explanation, and students speak English using formal language. 
While the learning indicators of the stories involve students answer some related question with the story, students respond or give a feedback based on their understanding, students convey the meaning of the story based on the information got from the story, and students answer some related questions to adverb place".

The four learning indicators above refer to the two considerations that teacher should use as guidance to integrate a value in the process of teaching English include narrative text. The first two learning indicators are for "King Arthur" story and the last two are for "The Donkey, The Table, and The Stick.

The first two indicators above led the teacher to instruct students to express their opinion in relation with students articulation in a certain sentence, to instruct students discuss the meaning of the difficult words identified, and to instruct students to answer some questions based on their understanding to the "King Arthur" story.

The other techniques that teacher implemented to integrate communicative value in teaching "King Arthur" were instructing students to share their understanding about the content of story with other and instructing to discuss the content of each structure of the texts.

The students were seemingly very active in this activity although teacher needed to stimulate them to say something about the story. finally there were some students involving in the discussion space that teacher provided.

The last two learning indicators are for "the Donkey, the Table, and the Stick" story which led the teacher to integrate the "communicative value. Those are "students convey the meaning of the story based on the information got from the story, and students answer some related questions to adverb place".

The indicators led the teacher to do five activities in the process of discussing the story namely instructing students to discuss the generic structure and the language features of the text written by their desk mate, instructing students to answer some question orally, instructing to exchange their text with 
others, instructing students to express their opinions about other students' work, and instructing students to give a feed back to their friends' opinion.

The students responded to the teacher's instruction by discussing the content of their friends' story and asking question to some sentences that other students wrote. Students also answer some questions asked and they explained to what they have already read. The class was very active at that time.

The instructions that teacher did in both "King Arthur and The Donkey, The Table, and The Stick" were teacher's tricks to train her students become communicative in every situation. Through those activities, students are expected to express their opinion in one case and listen the others opinion in other cases. So they can be survive in every places they live.

The fourth character that teacher integrated was "inquisitive". There are two considerations as the indicator of the value. Those are students read more English materials than teachers have recommended and students discuss with other students to enhance their capability in English. A learning indicator of "King Arthur" story refers to one of the indicator. It is "students analyze the structure of the King Arthur story". The learning indicator led the English teacher to integrate the inquisitive value in the process of discussing "King Arthur" story.

There are four techniques that teacher implemented to integrate the value. The techniques were instructing students to read more the story to determine whether the statements of other students right or no, instructing students to analyze the content of the story based on the story structure, instructing students to discuss intensively about the content of each structure, and instructing students to ask a question in related with the story.

Through the four instruction of the teacher, the students seemingly had good learning motivation to read the story deeply to determine whether their friends' opinion about the story is right or no. Some students also analyze the content of the story and asking some question about the plot and also the reason why they have to learn or discuss the story. 
The fifth character integrated $d$ is "hardworking". There are three consideration that teacher may use to select the value in the process of teaching English include in teaching narrative text. Those are student finish their task orderly and carefully, students use time as effective as possible to finish task, and students try to find references from various sources.

The learning indicators of "The Donkey, The Table, and The Stick" story refer to the considerations. They are students write narrative text by using their own words, students explain the content of structure of narrative text written, and students explain the language features used in their own narrative." Those three learning indicators led the English teacher to integrate the "Hardworking" value in the process of discussing the story.

The techniques that teacher implemented include instructing students to write narrative using the topic that they are interested in, and instructing students to understand their friends' writing. The two techniques made the students to write narrative text for fifteen minutes, and made the students to listen other students' explanation about the story they write.

The sixth value that teacher integrated in teaching narrative is "discipline." The teacher's proposition in selecting the value is the learning indicator of the topic. The indicator is "students use correct writing punctuation and student use language features correctly." The learning indicator is relevant with one of the three considerations that teacher should use in selecting the value. The considerations are students always finish their task in time, students are very careful to use punctuation in English, and students obey the role of learning English.

The techniques that teacher implemented to integrate the value comprise instructing students to finish the task on time. At that time students have to finish writing narrative for about fifteen minutes to thirty. And teacher instructed students to check diction, capitalization, and punctuation that they have to use in their writing. 
The student in the classroom was seemingly careful in writing the narrative text and almost students were finished on time. It means, students can finish their task for about fifteen minutes.

Through her instructions to the students in English classroom, the English teacher has tried to integrate all character values selected based on the learning indicator in her students' mind. The English teacher also tried to provide chance to her students to practice the character values especially when they are trained in the time when they discussed the two stories in their classroom. In this case, most students were only doing what teacher instructed.

Although the English teacher has deliberately integrated the character values in the process of teaching narrative but the result of internalization of the character values in students' practice especially in the process of discussing of the two stories has not been appeared. This case may be caused by limited time that researcher has to conduct an observation. So researcher cannot prove whether the integration of character values by the activities that teacher applied can help students to practice them in their daily practice or not.

Integrating character values for education context is necessary as Zeidler (2003) states that the basic goal of education is to create an intellect and character students. Through those two basic goals, the students are expected to master the all lessons that they learn and be able to practice the good thing and avoid the bad thing.

The English teacher is expected to integrate character every time when she taught because basically character integration is the implicit delivery of mediated learning experiences designed to promote a good attitude and behavior in the process of teaching and learning (White \& Warfa, 2011). The English teacher did not need to make new subject or material to integrate. The character is inserted only in the subject or lesson that she taught.

The way to integrate character values that the English teacher did in the Grade eleven F (XI-F) was inserting in teaching and learning activity. The option of integrating character values is relevant with what Mendiknas (2010) 
states that integrating character values in a lesson is the gist of character education.

The lesson that teacher used to insert the character values is narrative text. Narrative is story generally tell what happen, who did, what to whom and why. It consists of orientation, complication, and resolution (Dymock, 2007). At that time, there were two narrative texts used. First narrative is entitled King Arthur and second text entitled the Donkey, the Table, and the Stick. Through the two stories, the English teacher picked out some character values to be inculcated in students' mind to practice in their daily life

Tyra ((2011) states that using narrative to integrate character values is a good way for some reasons. First narrative text leads its self to teach specific character trait. Second, students are able to empathize with characters and understand character trait better than just being told information about each character. Third, narrative text can help students to cope emotion and problem they are facing.

To keep the teaching and learning process ran naturally, the English teacher did not tell students what kind of character values that they have to achieve. She usually taught the narrative text naturally, but in the process of discussing the narrative text, teacher tried to integrate some character values appropriate with the verb used in the indicator of teaching narrative. Because Mendiknas (2010) states that character values could be integrated in teaching and learning process by three principles: sustainable, inserted into a lesson, and character internalized not taught.

The English teacher did three things that possibly help students to practice the character values. The first, teacher became a model of character integrated. Teacher always practiced the character integrated in front of her students without asking her students to do so. Therefore, the students can practice the character naturally. The second, teacher created opportunities for students to be actively and meaningfully involve in the life of classroom. Yet, a student could interact with others. The interaction could help him to be independent and can help them not to rely on the teacher only. The third, 
teacher helped students to realize their full potential by asking them to write narrative text based on their understanding. The three factors that teacher implemented are some of Battistich (2007) seven techniques which should be implemented to integrate character values.

The technique that teacher did to select a particular character to integrate in the process of teaching and learning narrative is based on the learning indicator as Wahab (2011) states that the way to select appropriate character to integrate in teaching and learning process is by analyzing the indicator. As soon as teacher finished her analysis to the verb used, She selected the most appropriate character with the verb used in the learning indicators.

\section{CONCLUSION}

Based on the findings and discussion, it can be concluded that there are two steps that teacher did to integrate character values in teaching narrative. The first, teacher analyzed the operational verb used in the learning indicators. The English teacher then purposely selected the most character values with verb used. The second, teacher inserting the character values through her instruction to her students.

To insert the character values in the process of teaching and learning English especially in teaching narrative entitled "King Arthur and The donkey, The Table, and The Stick", teacher implemented seven techniques. The first was asking students to read the story based on its generic structure. The second was asking students to correct their friends' pronunciation. The third was asking students to identify the difficult word of the story and write them down on the whiteboard. The fourth was asking students to guess the meaning of the difficult words or look up dictionary to find the meaning. The fifth was asking or giving a comment to the story and asking other students to respond the question or comment. The sixth was asking students to identify the generic structure and the language feature of the story. And the seventh was asking students to conclude. 
While the techniques that teacher implemented to integrate character values in the process of teaching story entitled the Donkey, the Table, and the Stick include asking students to read the story from the orientation to the resolution, asking students to write story, asking students to discuss their writing with their desk mate, asking students to present their story in front of their friend, asking students to discuss the story presented, asking students to identify the structure and the features of the story, asking student to check the diction and English punctuation in the story the wrote, and asking students to answer the twelve question listed in their handbook.

The activities of integrating character values above shows that the teacher integrated the values by instructing students to do what she said. For instance, to integrate fond of reading, the English teacher instructed students to read story entitled "King Arthur" based on its structure, re-read the story to answer question related with the story, re-read the story to check other students answer, re-read the story to conclude the story.

Although the English teacher has purposely integrated the selected character values in the process of teaching narrative but the result of internalization of the character values in students' practice especially in the process of discussing of the two stories has not been appeared. This case may be caused by limited time that researcher has to conduct an observation. So researcher cannot know well whether the integration of character values by instructing students to do what teacher said can help students to be character or not.

\section{REFERENCES}

Battistich, Victor. (2007). Character Education, Prevention, and Positive Youth Development. Journal of Primary Prevention, 21, 1-10.

Bogdan, Robert, \& Biklen, Sari Knopp. (1992). Qualitative research for education : an introduction to theory and methods (2nd ed.). Boston: Allyn and Bacon. 
Bohlin, Karen E. (2005). Teaching Character Education through Literature, Awakening the moral imagination in secondary classrooms. London and New York: RoutledgeFalmer.

Cohen, Louis, Manion, Lawrence, \& Morrison, Keith. (2007 ). Research Method in Education (Sixth ed.). London and New York: Routledge

Dymock, Susan. (2007). Comprehension Strategy Instruction: Teaching Narrative Text Structure Awareness. International Reading Association, 61(2), 161167.

Hatch, J. Amos. (2002). Doing Qualitative Research in Education Setting: State University of New York Press, Albany.

Undang-Undang Republik Indonesia No. 20 Tahun 2003 Tentang Sistem Pendidikan (2003).

Ishii, Makoto. (2010). Implementing Character Education at Public Schools, Focusing on Sathya SAI Education in Human Values: A Case Study of Sathya SAI School Leceister, U.K. AND India. (Doctorate Program), Saybrook University, San Francisco, California.

King, Joyce Ann. (2008). An Evaluation of A Character Education Program at Elementary Schools. Nova Southeastern University. Southeastern.

Lickona, Tom, Schaps, Eric, \& Lewis, Catherine. (2007). CEP's Eleven Principles of Effective Character Education. Washington, DC: Character Education Partnership.

Mack, Natasha, woodsong, Cynthia, Macqueen, Kathleen M., Guest, Greg, \& Namey, Emily. (2005). Qualitative Research Methods: A Data Collector's Field Guide. North Carolina: Family Health International.

Mendiknas. (2010). Pengembangan Pendidikan Budaya dan Karakter Bangsa. Jakarta: Kementerian Pendidikan Nasional Badan Penelitian dan Pengembangan Pusat Kurikulum.

Miller, T. W. , Kraus, R. F., \& Veltkamp, L. J. . (2005). Character Education as a Prevention Strategy in School-Related Violence. Springer: Science and Business Media, Inc. 
Partnership, Character Education. (2008). National Schools of Character AwardWinning Practice (Vol. 2). United State of America: Character Education Partnership Publisher.

Poulson, Louise. (1998). The English Curriculum in Schools. London and New York: Cassell.

Salahuddin, Patricia Z. (2011). Character Education in a Muslim School: A Case Study of a Comprehensive Muslim School's Curricula. (Doctorate Program), Florida International University, Australia

Tyra, Courtney. (2011). Bringing Books to Life Teaching Character Education through Children's Literature, 5(Character Education), 1-16.

Wahab, Abd. (2011). Teknik Perumusan Silabus dan RPP Berkarakter. Pendidikan Karakter dan Budaya Bangsa, 2(Pendidikan Karakter dan Budaya Bangsa), 1-9.

White, Robert, \& Warfa, Nasir. (2011). Building Schools of Character: A Case Study Investigation of Character Education's Impact on School Climate, Pupil Behavior, and Curriculum Delivery. Journal of Applied Social Psychology, 45-60.

Zeidler, Dana L. (Ed.). (2003). The Role of Moral Reasoning on Socioscientific Issues and Discourse in Science Education (Vol. 19). Dordrecht, Boston, and London: Kluwer Academic Publishers. 